\title{
EFFECTS OF NATURAL BIOACTIVE COMPOUNDS ON MICROBIAL SAFETY AND QUALITY OF DAIRY PRODUCTS
}

\author{
Liliana Popescu*, ORCID ID: 0000-0003-3381-7511 \\ Technical University of Moldova, 168, Stefan cel Mare Bd., Chisinau, Republic of Moldova \\ *liliana.popescu@tpa.utm.md
}

Received: 03.23.2021

Accepted: 05.11.2021

\begin{abstract}
Dairy products are susceptible to contamination by foodborne pathogenic and spoilage microorganisms, which can result to a reduced shelf life of products as well as risks to the consumers'health. This determines the possible use of preservatives in the manufacturing process of dairy products. Consumers require healthy food, free of synthetic preservatives, looking for natural alternatives to ensure food safety. Just for this reason, natural ingredients are receiving increasing attention as substitutes for synthetic additives. Currently, research is focusing on the identification of natural antimicrobial agents, especially from plants such as fruits, vegetables, herbs and spices, as they contain significant amounts of compounds with antimicrobial activity. In addition, plants contain bioactive compounds, which could provide health benefits in preventing many diseases. This review aims to discuss the impact of natural antimicrobials on foodborne pathogenic and spoilage microorganisms in products, the antimicrobial efficacy of plant extracts and essential oils and the impact of their incorporation on the sensory characteristics of dairy products such as yogurts, cheeses, butter and ghee.
\end{abstract}

Keywords: spoilage, foodborne pathogen, natural antimicrobial, plant extracts, essential oil, shelf-life.

\section{Introduction}

Food safety is one of the main problems in the food industry, and there is always concern about the emergence of foodborne diseases among food producers, inspectors, researchers and consumers. The International Conference on Food Safety held in Addis Ababa in February 2019, and the International Forum on Food Safety and Trade held in Geneva in 2019, reiterated the importance of food safety in achieving the Sustainable Development Goals [1].

Besides contributing to food and nutrition security, a safe food supply also supports national economies, trade and tourism, and stimulates sustainable development. As the world's population grows, the intensification and industrialization of agriculture and animal production to meet increasing demand for food creates both opportunities and challenges for food safety [2]. These challenges place great responsibility on food industry producers to ensure food safety. Over the last decade, serious outbreaks of foodborne illness have emerged. Unsafe food poses a threat to global health, endangering the entire population. 
Infants, young children, pregnant women, the elderly and those with a underlying disease are particularly vulnerable. Every year, 220 million children suffer from diarrheal diseases and 96000 die [1].

The situation regarding acute diarrheal diseases in the Republic of Moldova is also considered unfavorable. About 20000 cases of the disease are registered annually, including 10-20 deaths in children under the age of 5 . In the structure of morbidity predominate children aged 0 - 17 years (60 - 75\%) and in the urban population, it is 1,9 times higher compared to the rural population. The morbidity index due to acute diarrheal diseases in 2017 is 464,4 per 100 thousand population and are increasing compared to 2016 by $9,4 \%$ [3].

The main cause of acute diarrheal diseases and food poisoning is the use of food contaminated with microbial pathogens, toxins or radioactive components. Foodborne pathogens (Clostridium botulinum, Staphylococcus aureus, Campylobacter jejuni, Bacillus cereus, Listeria monocytogenes, Cryptosporidium, Escherichia coli 0157: H7 etc.) are the main food safety concerns [4].

Therefore, the production of safe food is one of the most important priorities in the food industry. Various methods, including heat processing, decreased water activity, various packaging methods, irradiation, high pressure, high intensity pulsed electric field processing and the addition of preservatives have been used to produce safe food [5].

The addition of GRAS preservatives is one of the most widely used methods of ensuring food safety. Among the most used synthetic preservatives are nitrates, benzoates, sulfites and sorbates which, despite the benefits to food, such as safety and quality of products, pose risks to consumers due to the side effects that consumption can cause [6].

Many synthetic preservatives, such as butylhydroxyanizole $(\mathrm{BHA})$ and butylhydroxytoluene (BHT) have been used successfully to prevent food spoilage caused by lipid oxidation. In contrast, synthetic compounds have significant disadvantages, such as the risks of handling and the increase of chemical residues left in food. In addition, these preservatives could have negative consequences on consumers'health, with possible carcinogenic effects. Therefore, the food industry and research institutions are concerned with identifying natural preservatives as an alternative to synthetic ones, in order to meet consumer requirements for safe and healthy foods [7]

\section{Dairy spoilage microorganisms}

Globally, food spoilage caused by microorganisms still widely affects all types of food and causes food waste and loss, even in developed countries. It has been estimated that annual food losses worldwide reach up to $40 \%$ due to various factors, including food spoilage under the action of microorganisms [8].

Table 1

Key groups of spoilage bacteria known to contaminate pasteurized milk and their characteristics

\begin{tabular}{lll}
\hline Group & \multicolumn{1}{c}{$\begin{array}{c}\text { Examples of } \\
\text { genera/species }\end{array}$} & $\begin{array}{c}\text { Overview of key phenotypic characteristics } \\
\text { relevant to fluid milk spoilage }\end{array}$ \\
\hline \multirow{4}{*}{ Pseudomonas } & $\begin{array}{l}\text { P. fluorescens } \\
\text { P. fragi }\end{array}$ & - many strains can grow at $4{ }^{\circ} \mathrm{C}$ and below; \\
& $\begin{array}{l}\text { P. lundensis } \\
\text { P. putida }\end{array}$ & many strains can produce extracellular \\
& & enzymes (e.g., proteases and lipases); \\
& & some strains produce pigmented \\
& siderophores (e.g., pyoverdin).
\end{tabular}


Continuation Table 1

\begin{tabular}{|c|c|c|}
\hline Coliforms & $\begin{array}{l}\text { Enterobacter } \\
\text { Klebsiella } \\
\text { Citrobacter } \\
\text { Hafnia } \\
\text { Serratia }\end{array}$ & $\begin{array}{l}\text { - } \quad \text { many strains can grow at } 4^{\circ} \mathrm{C} \text { and below; } \\
\text { - } \quad \text { many strains can produce extracellular } \\
\text { enzymes (e.g., proteases and lipases). }\end{array}$ \\
\hline $\begin{array}{l}\text { Non-coliform, } \\
\text { non- } \\
\text { Pseudomonas } \\
\text { gram- } \\
\text { negatives }\end{array}$ & $\begin{array}{l}\text { Aeromonas } \\
\text { Flavobacterium } \\
\text { Acinetobacter } \\
\text { Non-coliform } \\
\text { Enterobacteriaceae }\end{array}$ & $\begin{array}{l}\text { - } \text { many strains can grow at } 4^{\circ} \mathrm{C} \text { and below; } \\
\text { - } \text { many strains can produce extracellular } \\
\text { enzymes (e.g., proteases and lipases). }\end{array}$ \\
\hline $\begin{array}{l}\text { Gram-positives } \\
\text { sporeformers }\end{array}$ & Bacillus cereus & 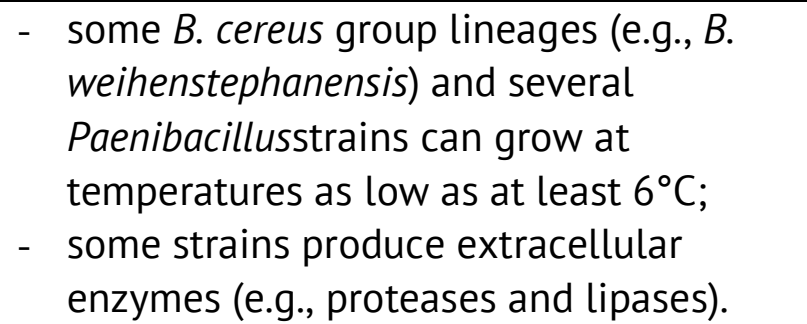 \\
\hline
\end{tabular}

Alteration of milk is primarily due to the increase in the population of psychrotrophic microorganisms that trigger the lipolysis reactions of fatty acids and proteolysis reactions of milk proteins, even at a temperature of $0^{\circ} \mathrm{C}$ (the optimal development temperature is $20 \ldots 30^{\circ} \mathrm{C}$ ) [9]. Lipolysis of milk lipids leads to the accumulation of free fatty acids, shortchain glycerides and to the appearance of unwanted flavoring of milk and other dairy products.

Quality problems and defects associated with the presence of lipolysis in dairy products can be described as rancid, butyric, bitter, soapy and astringent. Once lipolysis produces detectable flavors, it is not possible to remove them from the product [5]. In addition, the hydrolysis of milk proteins under the action of proteases produced by Pseudomonade, Aeromonade, Serratia and Bacillus spp. leads to the formation of bitter peptides and amino acids, to the gelation and coagulation of milk [10, 11, 12, 13].

Alteration of milk is mediated by lipases that are naturally present in milk as well as lipases secreted by psychotrophic bacteria that can contaminate milk during milking, storage and transport $[12,14]$. One of the most important properties of these bacterial enzymes is thermostability $[10,15]$.

Therefore, it is important to develop good practices and strategies to reduce the risks of milk contamination before pasteurization, as the action of residual enzymes during storage will shorten the shelf life of the milk [10].

When making cheese and butter, flavor defects caused by lipolysis may occur before or after manufacture, while yogurt is less susceptible to lipolysis defects due to technological factors such as low $\mathrm{pH}$, low storage temperature and short shelf life $[11,16]$.

Although various applications of herbs and spices are being studied to capitalize on them as new food ingredients, there is a lack of information on the effect of adding these extracts on the lipolysis or proteolysis process in dairy products.

This should be considered, as some ingredients, such as pepper, promote lipase activity in cheese, leading to the accumulation of fatty acids and the appearance of rancid flavor [5]. 


\section{Foodborne pathogens in dairy products}

Farm animals represent a major source of pathogens that can be transferred milk $[17,18]$. Staphylococcus aureus, Salmonella spp., Listeria monocytogenes, Escherichia coli 0157: H7 and Campylobacter are the most common potential pathogens associated with milk or dairy products in industrialized countries [19, 20]. Foodborne bacteria can contaminate dairy products at any point along the production chain: milking, storage or packaging [21].

Reports from developed countries indicated that milk and dairy products are implicated in $1 . . .6 \%$ of the total bacterial foodborne outbreaks [22], with $39,1 \%$ attributed to milk, $53,1 \%$ to cheeses and $7,8 \%$ to other dairy products [23].

The severity of food poisoning caused by the consumption of raw milk products depends on several factors, such as the pathogenicity of the bacterial strain, the number of ingested microorganisms, the physiological state of the microorganism and the health of the consumer at the moment of ingestion [24].

Heat treatment of milk (pasteurization or UHT treatment) aims to inactivate pathogenic bacteria. However, inadequate pasteurization or post-pasteurization contamination can lead to recontamination of milk if hygiene measures are not followed at the farm, leading to incidences of food poisoning [25]. Outbreaks of foodborne illness have been mainly linked to the consumption of raw milk or unpasteurised milk products, such as raw milk cheeses, whose consumption is constantly increasing due to a growing demand for natural and unprocessed foods [26, 27].

The number of outbreaks of fresh dairy poisoning due to contamination with pathogens is less common, although some cases have been reported for yogurt and fermented milk. In these products, the acidity of the matrix acts as a barrier in the growth of pathogenic bacteria. However, milk must be pasteurized because some pathogens, such as E. coli 0157: H7, can also grow in acidic environments [4].

Outbreaks caused by the consumption cheese made from unpasteurized milk are often caused by: Salmonella (34\%), Campylobacter (26\%), Brucella (13\%), Escherichia coli (11\%) and Shiga toxin Escherichia coli (11\%) [28]. Listeria monocytogenes is inactivated by pasteurization, however worldwide Listeria monocytogenes has been implicated in numerous outbreaks caused by the consumption of contaminated milk and dairy products [29, 30]. In 2015, dairy products were identified as the main sources of listeriosis [31, 32]. Raw milk can be contaminated with Listeria monocytogenes from unhygienic equipment during milking, storage or transportation to processing enterprises where hygienic control measures are not followed [33]. Due to its high mortality rate, listeriosis is, after salmonellosis, the second most frequent cause of foodborne infection-related deaths in Europe [17, 29]. However, outbreaks from Listeria monocytogenes are not common compared with those caused by pathogens such as Salmonella [34, 35].

Staphylococcus aureus can multiply in milk, especially if its storage temperature is higher than $10^{\circ} \mathrm{C}$. Staphylococcus aureus can develop staphylococcal enterotoxins in milk, which are responsible for staphylococcal food poisoning [36, 37]. This bacterium is commonly found in a wide variety of mammals and birds and can be transferred to food mainly by dairy animals that have mastitis and by human carriers during food processing [38]. Staphylococcus aureus can have a broad occurrence in raw dairy products, with frequencies between 5 and 100\% in cheeses [24]. The number of Staphylococcus aureus in raw milk or raw milk cheeses needs to be less than $10^{4} \mathrm{cfu} / \mathrm{g}$, according to national 
regulations [39]. Foods of high protein content such as milk and dairy products, meat, meat products and bakery products favor the growth of bacteria, and these types of foods have been frequently incriminated in outbreaks of Staphylococcus aureus [40].

Staphylococcus aureus is present in raw materials and food and can be inactivated with heat treatment, but enterotoxins are heat-resistant. In the dairy industry, the following milk pasteurisation regimes are used: $72^{\circ} \mathrm{C}$ for 15 seconds or $63^{\circ} \mathrm{C}$ for 30 minutes, to ensure inactivation of bacteria and toxins [10].

Salmonella spp. is the most frequent cause of foodborne outbreaks, and human salmonellosis is the second most frequently reported zoonosis in the European Union [41]. Milk is a food with a high chance of contamination by Salmonella spp. [42], mainly before leaving the farm, usually due to fecal contamination during the milking process [22]. Additionally, Salmonella spp. can be transmitted to humans through the consumption of contaminated dairy products [41], especially unpasteurized or insufficiently pasteurized milk and cheese [22]. The main source of Shiga toxin-producing Escherichia coli are ruminants, contaminating milk through subclinical mastitis or feces, and bacteria can persist in milking equipment [17].

One of the most important tasks of the food industry in the field of food safety is to eliminate or at least reduce contamination with foodborne pathogens [43].

\section{Antimicrobial agents and the safety of dairy products}

Food preservatives are food additives that extend the shelf life of food by protecting against damage caused by microorganisms. Different types of preservatives include antimicrobial agents, antifungals, synergistic antimicrobial agents, bacteriophage control agents and fungistatic agents [44]. Currently, research focuses on the identification of natural antimicrobial agents, especially from plants [45] such as fruits, vegetables, herbs and spices [46, 47, 48,49,50], because they contain significant amounts of compounds with antimicrobial activity.

As shown by in vitro experiments, plants produce secondary metabolites that have high antimicrobial activity [46, 51]. Secondary antimicrobial metabolites of herbs are generally classified into three major classes: phenolic compounds, terpenes and alkaloids (Figure 1). Numerous studies have shown that the antimicrobial activity of herbs is determined by the potential of secondary metabolites to:

- promote cell wall disruption and lysis;

- induce the production of reactive oxygen;

- inhibit biofilm formation;

- inhibit the construction of the cell wall;

- inhibit microbial DNA replication;

- inhibit energy synthesis;

- inhibit bacterial toxins to the host [52, 53,54, 55, 56].

Additionally, these compounds can prevent antibacterial resistance, as well as synergists to antibiotics, which can eventually destroy pathogenic microorganisms [51]. In the Republic of Moldova there is a vast and historical experience in the aromatic and medicinal plant industry. Being an agricultural country with favorable pedoclimatic conditions, the Republic of Moldova has an enormous potential in the cultivation, processing and marketing of aromatic and medicinal plants, which is currently not fully explored [57]. 


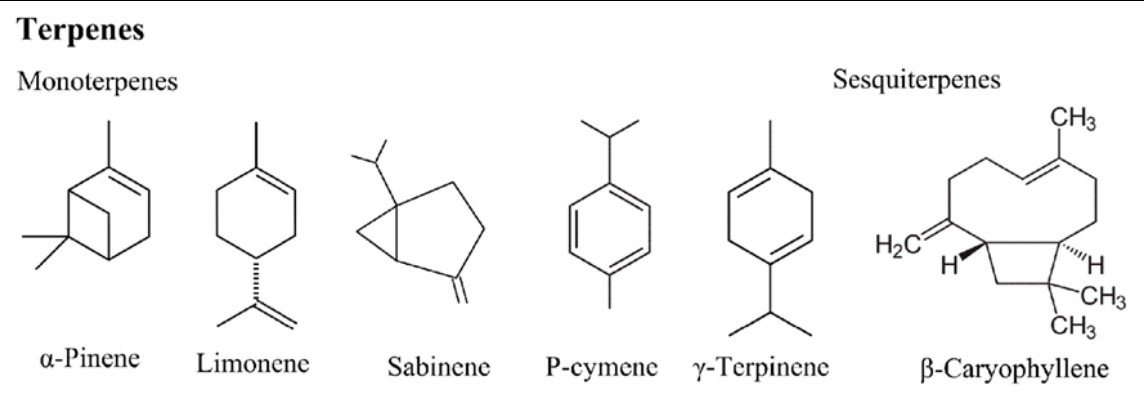

Terpenoids

Monoterpenoids

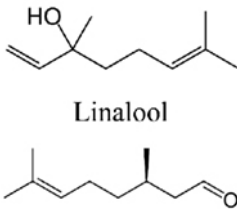

Citronellal

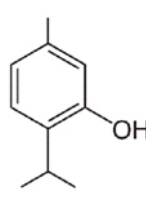

Thymol

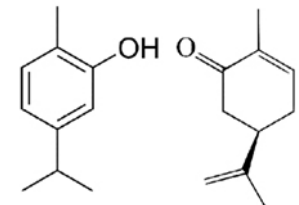

Carvone

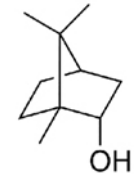

Borneol

Phenylpropanoids<smiles>O=C/C=C/c1ccccc1</smiles>

Cinnamaldehyde<smiles>C=CCc1ccc(O)c(OC)c1</smiles><smiles>COc1cc(C=O)ccc1O</smiles><smiles>C=CCc1ccc2c(c1)OCO2</smiles>

Others<smiles>C=CCN=C=S</smiles>

Allyl-isothiocyanate<smiles>C=CCS[S+]([O-])CC=C</smiles>

Allicin

Figure 1. The chemical structure of antibacterial bioactive compounds in herbs [56].

\section{Potential application of herbs in dairy products}

Table 2 selects the articles referring to the antimicrobial activity of aromatic plants applied in the production of dairy products.

Hanifah et al. (2016) added L. acidophilus and roselle extract in the manufacture of goat milk based-yoghurt. These yoghurt was characterized by increased antimicrobial activity and extensive selectivity for Gram positive and Gram negative bacteria (Bacillus cereus, Escherichia coli, Staphylococcus aureus and Salmonella Typhi), which might be attributed to the production of higher antimicrobial compounds, including antimicrobial peptides and organic acid [58]. Also, Ghalem and Zouaoui (2013) supplemented yoghurt with Rosmarinus officinalis oil at ratio of 0,$14 ; 0,21 ; 0,29$ and $0,36 \mathrm{~g} / \mathrm{L}$ and kept it up to 21 days. Panelists gave the maximum score for taste, flavor, and texture, to the herbal yoghurt supplemented with $0,14 \mathrm{~g} / \mathrm{L}$ of essential oil. Addition of $R$. officinalis essential oil improved the qualities of yoghurt by decreasing $\mathrm{pH}$, lactose values and dry matter but raised the titratable acidity, proteins, ash and fat contents [59].

El-Sayed et al. (2017) reported that the supplementation of Labneh with different ratios $(100,150$ and $200 \mathrm{mg} / \mathrm{ml})$ of Moringa oleifera oil increased the total solid, fat, total volatile fatty acid, DPPH scavenging activity, tocopherols and total lactic acid bacterial counts content of labneh.

The M. oleifera oil displayed a great effect against Gram-positive, Gram-negative, yeast and fungal strains with the increase of the ratios of $M$. oleifera oil [60]. 
Table 2

Selected publications on the antimicrobial activity plantes in dairy products

\begin{tabular}{|c|c|c|c|}
\hline $\begin{array}{l}\text { Type of dairy } \\
\text { products }\end{array}$ & Type of herbs and spices & Microorganisme type & Reference \\
\hline \multicolumn{4}{|c|}{ Yoghurt } \\
\hline $\begin{array}{l}\text { Goat milk } \\
\text { based- } \\
\text { yoghurt }\end{array}$ & $\begin{array}{l}\text { Roselle (Hibiscus sabdariffa } L \text { ) } \\
\text { extract }\end{array}$ & $\begin{array}{l}\text { Bacillus cereus, Escherichia } \\
\text { coli, Staphylococcus aureus and } \\
\text { Salmonella Typhi }\end{array}$ & [58] \\
\hline Yoghurt & $\begin{array}{l}\text { Rosmarinus officinalis oil ( } 0.14 \text {, } \\
0.21,0.29 \text {, and } 0.36 \mathrm{~g} / \mathrm{L})\end{array}$ & 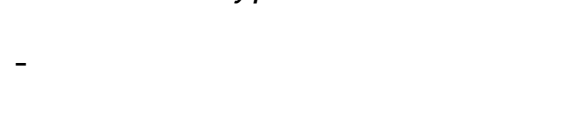 & [59] \\
\hline Labneh & $\begin{array}{l}\text { Moringa oleifera oil }(100,150 \\
\text { and } 200 \mathrm{mg} / \mathrm{ml})\end{array}$ & $\begin{array}{l}\text { M. oleifera oil displayed well } \\
\text { effect against Gram-positive, } \\
\text { Gram-negative, yeast and } \\
\text { fungal }\end{array}$ & {$[60]$} \\
\hline \multicolumn{4}{|l|}{ Cheese } \\
\hline $\begin{array}{l}\text { Fresh cow } \\
\text { Cheese }\end{array}$ & $\begin{array}{l}\text { Satureja hortensis L. (dry plant } \\
(0.5 . . .1 .5 \%) \text {, alcoholic extract } \\
\text { and essential oil }(0.1 \%, 0.25 \% \text {, } \\
0.5 \%)\end{array}$ & $\begin{array}{l}\text { Staphylococcus aureus, total } \\
\text { number of germs }\end{array}$ & {$[61]$} \\
\hline $\begin{array}{l}\text { Fresh sheep } \\
\text { cheese }\end{array}$ & $\begin{array}{l}\text { T. vulgaris } L . \text { and Origanum } \\
\text { vulgare } L . \text { essential oil ( } 4 \text { and } 8 \\
\mu \mathrm{L} / \mathrm{mL} \text { ) }\end{array}$ & S. aureus & {$[62]$} \\
\hline Wagashi & $\begin{array}{l}\text { Ocimum gratissimum (200, 400, } \\
600,800,1000 \mathrm{mg} / \mathrm{L})\end{array}$ & $\begin{array}{l}\text { Aspergillus } \\
\text { tamarii, } \\
\text { Fusus, Aspergillus } \\
\text { Fusarium poae, } \\
\text { Penicillium citrinum and } \\
\text { Penicillium griseofulvum }\end{array}$ & [63] \\
\hline $\begin{array}{l}\text { Domiati } \\
\text { cheese }\end{array}$ & $\begin{array}{l}\text { Nigella sativa oil ( } 1 \% \text { and } 0.2 \% \\
(\mathrm{w} / \mathrm{w}))\end{array}$ & $\begin{array}{l}\text { Staphylococcus } \begin{array}{l}\text { aureus, } \\
\text { Salmonella }\end{array} \text { enteritidis, } \\
\text { Escherichia coli and Listeria } \\
\text { monocytogenes }\end{array}$ & {$[64]$} \\
\hline \multicolumn{4}{|c|}{ Butter and ghee } \\
\hline Ghee & Dry clove and rosemary & - & [65] \\
\hline $\begin{array}{l}\text { Butter } \\
\text { Ghee } \\
\text { manufactured } \\
\text { by creamery } \\
\text { buffalo butter }\end{array}$ & Arjuna alcoholic extract (7\%) & - & [66] \\
\hline
\end{tabular}

Results of studies conducted by Erselia et al. 2018, have shown that the addition of Satureja hortensis L. dry plant and essential oil led to a reduction in the total number of germs, this reduction being more significant when the essential oil was used.

The antimicrobial effect of Satureja hortensis L. dry plant in various proportions $(0,5-$ $1,5 \%)$ and essential oil (0,1\%; 0,25\%; 0,5\%), on fresh cow's cheese, was assessed after 3 and 7 days [61]. 
In a study by Amatiste et al. (2014), the antimicrobial activity of T. vulgaris L. and Origanum vulgare L. essential oils against $S$. aureus in fresh sheep cheese was assessed. The determined MIC and MBC of the essential oils were 4 and $8 \mu \mathrm{L} / \mathrm{mL}$, respectively. In addition, it was observed the aforementioned essential oils had no effect on $S$. aureus count in cheese samples during 7 days of storage which was attributed to the interaction of active components of essential oils with cheese matrix [62].

Effect of essential oil from Ocimum gratissimum (200, 400, 600, 800 or 1000 mg/L) was assessed against six fungi including Aspergillus flavus, Aspergillus tamarii, Fusarium poae, Fusarium verticillioides, Penicillium citrinum and Penicillium griseofulvum isolated from a traditional cheese named wagashi. It was noted that mycelia growth was reduced by increasing the essential oil level. A significant fungistatic activity against all the examined species was observed with MIC values, ranging from 800 to $1000 \mathrm{mg} / \mathrm{L}$ [63]. Mahgoub et al. (2013) studied the effect of adding $0,1 \%$ and $0,2 \%(w / w)$ of Nigella sativa oil to Domiati cheese on the inhibition of foodborne pathogens (Staphylococcus aureus, Salmonella enteritidis, Escherichia coli in addition to Listeria monocytogenes) inoculated in cheese during storage. Addition of $0,2 \%$ oil showed the most effective antimicrobial potential on pathogens and improved the physicochemical and sensory properties of the cheese [64].

Najgebauer et al. (2009) evaluated the storage stability of butter prepared from sour cream with $2 \%$ addition of dried herbs (sage or rosemary). They concluded that the addition of rosemary herb was more effective in delaying lipolysis in butter than sage, but both supplemented products had increased oxidative stability through storage than the control. TBA analyses test exposed that the sage and rosemary butters contained significantly smaller concentrations of secondary oxidative products like malonoaldehyde and ketones than the butter without herbs [66]. Parmar and Khamrui (2017) found that the ghee manufactured by creamery buffalo butter supplemented with $7 \%$ arjuna alcoholic extract had maximum phytosterol content with suitable sensorial characteristics [67].

\section{Effect of herbs on the sensory properties of dairy products}

Adding herbs as flavor to some varieties of cheese is already a common practice. Therefore, the acceptance of cheese with essential oils and extracts can be facilitated if consumers are already accustomed to this type of product. However, essential oils and extracts from herbs often have a strong aroma even when used in low concentrations, which can cause a negative sensory impact, with a possible rejection of the product, making it a limiting factor in the use of herbs and their components. Acceptance of the product is extremely important because only a high antimicrobial effect is not sufficient if the consumer does not accept it from a sensory point of view. Among the plant extracts and essential oils added to cheeses, oregano, black cumin, green pepper, rosemary, thyme and lemon grass have led to good sensory acceptance $[68,69]$.

However, the concentration of these substances applied in cheeses should be carefully considered, due to the possible negative impacts on sensory properties. To minimize the possible negative effects of plants and their constituents in the aroma of products, a combination of different extracts and volatile oils was investigated, which can lead to a good antimicrobial effect at lower individual concentrations. These combined compounds may, in some cases, have a higher antimicrobial activity than when added separately, thus having a synergistic effect $[51,60,61]$. 
The combined use of these natural compounds with emerging technologies such as ultrasound, high pressure and electrical pulses may also allow the use of lower concentrations of essential oils, as these technologies frequently affect the cell membrane, thus facilitating penetration and antimicrobial activity.

Also, the application of essential oils together with other antimicrobial agents and preservatives may be more effective in preventing microbial growth and increasing the safety and quality of cheese [70].

\section{Conclusions}

Plant extracts and essential oils have been shown to be natural preservatives and antioxidants with significant inhibitory activity against foodborn pathogens and spoilage microorganisms, thus helping to extend the shelf life of the dairy product. The main compounds of aromatic plants, including thymol, carvacrol, eugenol, carvona and cinnamaldehyde are mainly responsible for achieving antimicrobial activity through various mechanisms, such as increasing cell permeability and interfering with enzymes involved in energy production that eventually lead to cell death.

However, given the losses during processing and their stability during storage, several studies should be performed to determine the concentration of extracts and essential oils added in dairy products, as well as the action of these plant antimicrobial compounds on lactic acid bacteria.

In addition, there is a need to expand and deepen sensory studies related to the use of essential oils and plant extracts in various dairy products, in order to better understand the possible impacts on consumer acceptance.

\section{Acknowledgments}

This work was benefited from support through the project 20.80009.5107.09 "Improvement of food quality and safety by biotechnology and food engineering" and 20.00208.1908.03 "Principles of dairy processing correlated to balanced nutrition and food safety", funded by the Government Republic of Moldova.

\section{References}

1. Fung F., Wang H-S., Menon S. Food safety in the 21st century. Biomedical Journal, 2018, 41 (2), pp. 88-95.

2. Kamboj S., Gupta N., Bandral J., Gandotra G., Anjum N. Food safety and hygiene: A review. International Journal of Chemical Studies, 2020; 8(2), pp. 358-368.

3. https://old.ansp.md/in-perioada-01-31-mai-2019-luna-nationala-de-profilaxie-a-bolilor-diareice-acuteintoxicatiilor-alimentare-si-holerei/

4. Bintsis T. Foodborne pathogens. AIMS Microbiology, 2017, 3(3), pp. 529-563.

5. Deeth H. C. Lipolysis and hydrolitic rancidity. In: Encyclopedia of Dairy Sciences, 2011, pp. 721-726.

6. Sultana N., Alimon A. R., Haque K.S., Sazili A. Q., Yaakub H., Hossain S. M. J. The effect of cutting interval on yield and nutrient composition of different plant fractions of Moringa oleifera tree. Journal of Food, Agriculture and Environment, 201412 (2), pp. 599-604.

7. Campelo M. C. S., Medeiros J. M.S., Silva J. B. A. Natural products in food preservation. International Food Research Journal, 2019, 26(1), pp. 41 - 46.

8. Gustavsson J., Cederberg C., Sonesson U., Otterdijk R., Maybeck A. Global Food Losses and Food Waste: Extent, Causes, and Prevention. Düsseldorf: FAO. 2011.

9. Ribeiro Júnior J. C., De Oliveira A. M., Silva F. D. G., Tamanini R., De Oliveira A. L. M., Beloti V. The main spoilage-related psychrotrophic bacteria in refrigerated raw milk. Journal of Dairy Sciences, 2018, 101, pp. 75-83.

10. Apostu S. Microbiology of food products. Vol. 2. Cluj-Napoca, Risoprint, 2009. 401p. (rom) 
11. Baglinière F., Jardin J., Gaucheron F., De Carvalho A. F., Vanetti M. C. D. Proteolysis of casein micelles by heat-stable protease secreted by Serratia liquefaciens leads to the destabilisation of UHT milk during its storage. Dairy Journal, 2017, 68, pp. 38-45.

12. Baglinière F., Tanguy G., Salgado R.L., Jardin J., Rousseau F., Robert B., Harel-Oger M., Vanetti M.C.D., Gaucheron F. A new heat stable protease able to destabilize UHT milk during its storage. Food Chemistry, 2017, 229, pp. 104-110.

13. Lu M., Wang N. S. Spoilage of milk and dairy products. In: The Microbiological Quality of Food-Foodborne Spoilers, Woodhead Publishing Limited: Cambridge, UK, 2017, pp. 151-178.

14. Serra M., Trujillo A. J., Pereda J., Guamis B., Ferragut V. Quantification of lipolysis and lipid oxidation during cold storage of yogurts produced from milk treated by ultra-high pressure homogenization. Journal Food Engineering, 2008, 89, pp. 99-104.

15. Rehman S. U., Farkye N. Y. Phosphatases. In Encyclopedia of Dairy Sciences, Atlanta, GA, USA, 2011, pp. 314318.

16. Tatarov P. Lipid oxidation. In: Food Chemistry, Ed. MS Logo, Chisinau, 2017, pp. 256-268. (rom)

17. Arqués J. L., Rodríguez E., Langa S., Landete J. M., Medina M. Antimicrobial activity of lactic acid bacteria in dairy products and gut: effect on pathogens. BioMed Research International, 2015, pp. 1-9.

18. Cancino-Padilla N. et al. Foodborne bacteria in dairy products: Detection by molecular techniques. Ciencia e Investigación Agraria, 2017, 44(3), pp. 215-229.

19.Jakobsen R. A., Heggebø R., Sunde E. B., Skjervheim M. Staphylococcus aureus and Listeria monocytogenes in Norwegian raw milk cheese production. Food Microbiology, 2011, 28, pp. 492-496.

20. Martin N., Boor K., Wiedmann M. Effect of post-pasteurization contamination on fluid milk quality. Journal of Dairy Science, 2018, vol. 101, pp. 861-870.

21. Tomat D., Balagué C., Casabonne C., Verdini R., Quiberoni A. Resistance of foodborne pathogen coliphages to additives applied in food manufacture. LWT - Food science and technology, 2016, 67, pp. 50-54.

22. Ahmed A. M., Shimamoto T. Isolation and molecular characterization of Salmonella enterica, Escherichia coli 0157:H7 and Shigella spp. from meat and dairy products in Egypt. Journal Food Microbiology, 2014, 168169 , pp. 57-62.

23. Claeys W. L., Cardoen S., Daube G., De Block J., Dewettinck K., Dierick K. Raw or heated cow milk consumption: review of risks and benefits. Food Control, 2013, 31, pp. 251-262.

24. Verraes $C$. et al. A review of the microbiological hazards of dairy products made from raw milk. Dairy Journal, 2015, 50, pp. 32-44.

25. Forsythe S. J. The Microbiology of Safe Food. 2nd ed., Wiley Blackwell: Hoboken, NJ, USA, 2010.

26. Yoon Y., Lee S., Choi K. H. Microbial benefits and risks of raw milk cheese. Food Control. 2016, 63, pp. 201215.

27. Fusco V., Quero. G.M. Culture-dependent and culture-independent nucleic-acid-based methods used in the microbial safety assessment of milk and dairy products. Food Science Food Safety, 2014, 13, pp. 493-537.

28. Gould L.H., Mungai E., Behravesh C. B. Outbreaks attributed to cheese: differences between outbreaks caused by unpasteurized and pasteurized dairy products. Foodborne Pathogens and Disease, 2014, 11, pp. 545-551.

29.Dalzini E., Bernini V., Bertasi B., Daminelli P., Losio M.N. Varisco. G. Survey of prevalence and seasonal variability of Listeria monocytogenes in raw cow milk from Northern Italy. Food Control, 2016, 60, pp. 466470.

30. Wang J., X. Feng J. Xie Chen J.C., Dua X., Luo J., Lu X., Wang S. Rapid detection of Listeria monocytogenes in milk using confocal micro-raman spectroscopy and chemometric analysis. Journal Food Microbiology, 2015, 204, pp. 66-74.

31.Jackson B.R. et. al. Implementation of nationwide real-time whole-genome sequencing to enhance listeriosis outbreak detection and investigation. Clinical Infectious Diseases, 2016, 63(3), pp. 380-386.

32. Quero G. M., Santovito E., Visconti A., Fusco V. Quantitative detection of Listeria monocytogenes in raw milk and soft cheeses: culture- independent versus liquid- and solid-based culture dependent real time PCR approaches. LWT-Food Science and Technology, 2014, 58, pp. 11-20.

33. Melo J., Andrew P. W., Faleiro M. L. Listeria monocytogenes in cheese and the dairy environment remains a food safety challenge: the role of stress responses. Food Research International, 2015, 67, pp. 75-90.

34. Todd E. C. D., Notermans S. Surveillance of listeriosis and its causative pathogen, Listeria monocytogenes. Food Control, 2011, 22, pp. 1484-1490. 
35. Ahmed R., Soule G., Demczuk W. H., Clark C., Khakhria R., Ratnam S. Epidemiologic typing of Salmonella enterica serotype enteritidis in a Canada - wide outbreak of gastroenteritis due to contaminated cheese. Journal of Clinical Microbiology, 2000, 38(6), pp. 2403-2406.

36. Casciaro B., Calcaterra A., Cappiello F., Mori M., Loffredo M.R., Ghirga F., Mangoni M.L., Botta B., Quaglio D. New potential antimicrobial alkaloid for the treatment of Staphylococcus aureus - induced infections. Toxins, 2019, 11, 511.

37. Rosengren A.., Fabricius A., Guss B., Sylvén S., Lindqvist R. Occurrence of foodborne pathogens and characterization of Staphylococcus aureus in cheese produced on farm-dairies. Journal Food Microbiology, 2010, 144, pp. 263-269.

38. Hennekinne J., De Buyser M., Dragacci S. Staphylococcus aureus and its food poisoning toxins: characterization and outbreak investigation. FEMS Microbiology Reviews, 2012, 36, pp. 815-836.

39. Government Decision no. 221 of 16.03.2009 regarding the approval of the Rules on microbiological criteria for food products (rom) https://www.legis.md/cautare/getResults?doc_id=119439\&lang=ro

40. Fetsch A., Contzen M., Hartelt K., Kleiser A., Maassen S., Rau J. Staphylococcus aureus food-poisoning outbreak associated with the consumption of ice-cream. Journal Food Microbiology, 2014.,187, pp. 1-6.

41. Vignaud M. et al. MLVA for Salmonella enterica subsp. enterica serovar Dublin: development of a method suitable for inter-laboratory surveillance and application in the context of a raw milk cheese outbreak in France in 2012. Frontiers in Microbiology, 2017, 8, 295.

42. Riyaz-Ul-Hassan S., Verma V., Qazi G.N. Real-time PCR-based rapid and culture-independent detection of Salmonella in dairy milk - addressing some core issues. Letters in Applied Microbiology, 2013, 56, pp. 275282.

43. Giacometti J., Buretić Tomljanović A., Josić D. Application of proteomics and metabolomics for investigation of food toxins. Food Research, 2013, 54, pp. 1042-1051.

44. Codex Alimentarius General Standard for Food Additives Codex Stan 192-1995. Food and Agriculture Organization of the United Nations: Rome, Italy, 2017.

45. Thielmann J., Kohnen S., Hauser C. Antimicrobial activity of Olea europaea Linné extracts and their applicability as natural food preservative agents. International Journal of Food Microbiology, 2017, 251, pp. 48-66.

46. Faraja D. et al. Antimicrobial properties and mechanism of action of some plant Extracts against food pathogens and spoilage Microorganisms Front Microbiology, 2018, 9, pp. 1639.

47. Khalil A. Antimicrobial activity of ethanolic extracts of Ocimum basilicum leaf from Saudi Arabia. Biotechnology. 2013, 12, pp. 61-64.

48. Kumar A., Shukla R., Singh P., Prakash B., Dubey N. K. Chemical composition of Ocimum basilicum L. essential oil and its efficacy as a preservative against fungal and aflotaxin contamination of dry fruits. International Journal of Food Science and Technology, 2011, 46, 1840-6.

49. Mahboubi M., Kazempour N. Chemical composition and antimicrobial activity of Satureja hortensis and Trachyspermum copticum essential oil. Iran Journal of Microbiology, 2011, 3, pp. 194-200.

50. MasKović P. et al. Summer savory extracts prepared by novel extraction methods resulted in enhanced biological activity. Industrial Crop and Produnts, 2017, 109, pp. 875-881.

51. Mickymaray S. Efficacy and mechanism of traditional medicinal plants and bioactive compounds against clinically important pathogens antibiotics (Basel). Antibiotics, 2019, 8(4), 257.

52. Bajpai V. K., Sharma A., Baek K. H. Antibacterial mode of action of Cudrania tricuspidatafruit essential oil, affecting membrane permeability and surface characteristics of food-borne pathogens. Food Control, 2013, 32, pp. 582-590.

53. El-Adawi H. Inhibitory effect of grape seed extract (GSE) on cariogenic bacteria. Journal of Medicinal Plants Research, 2012, 6.

54. Ganesan K., Xu B. Polyphenol-rich dry common beans (Phaseolus vulgaris L.) and their health benefits. Journal of Molecular Sciences, 2017, 18, 2331.

55. Ganesan K., Xu B. Polyphenol-rich lentils and their health promoting effects. Journal of Molecular Sciences, 2017, 18, 2390.

56. Hyldgaard M., Mygind T., Meyer R. L. Essential oils in food preservation: Mode of action, synergies, and interactions with food matrix components. Frontiers in Microbiology, 2012, 3, pp. 1-24.

57. National program for the development of the Aromatic and Medicinal Plants sector for the period 20202030 (rom) https://www.ucipifad.md/noutati/programului-national-de-dezvoltarea-a-sectorului-de-ovinesi-caprine-pentru-perioada-2020-2030/ 
58. Hanifah R., Arief I.I., Budiman C. Antimicrobial activity of goat milk yoghurt with addition of a probiotic Lactobacillus acidophilus IIA - 2B4 and roselle (Hibiscus sabdariffa L) extract. Food Research Journal, 2016,23 (6), pp. 2638-2645.

59. Ghalem B.R., Zouaoui B. Microbiological, physico-chemical and sensory quality aspects of yoghurt enriched with Rosmarin usofficinalis oil. African Journal Biotechnology, 2013, 12 (2), pp. 192-198.

60.El-Sayed S. M., El-Sayed H. S., Salama H. H., Abo El-Nor S.A.H. Improving the nutritional value and extending shelf life of labneh by adding Moringa oleifera oil. Journal Dairy Sciences, 2017,12 (2), pp. 8192.

61. Alexa E. et al. Chemical composition and antimicrobial potential of Satureja hortensis L. in fresh cow cheese. Hindawi, Journal of Food Quality, 201810 p.

62. Amatiste S., Sagrafoli D., Giacinti G., Rosa G., Carfora V., Marri N., Rosati R. Antimicrobial activity of essential oils against Staphylococcus aureus in fresh sheep cheese. Italian Journal of Food Safety, 2014, 3(3), pp. $148-150$.

63. Sessou P. et al. Chemical composition and in vitro antifungal activity of Zingiber officinale essential oil against foodborne pathogens isolated from a traditional cheese wagashi produced in Benin. International Journal of Biosciences, 2012, 2 (9), pp. 20-28.

64. Mahgoub S., Ramadan M.F., El-Zahar K. Cold pressed Nigella sativa oil inhibits the growth of food-borne pathogens and improves the quality of Domiati cheese. Journal Food Safety, 2013, 33, pp. 470-480.

65. Maiza A. et al. Butter oil (ghee) enrichment with aromatic plants: Chemical characterization and effects on fibroblast migration in an in-vitro wound healing model. Arabian Journal of Chemistry, 2020, 13 (12), pp. 8909-8919.

66. Najgebauer L.D., Grega T., Sady M. The quality and storage stability of butter made from sour cream with addition of dried sage and rosemary. Biotechnology Animal Husbandry, 2009, 25, pp. 753-761.

67. Parmar P., Khamrui K. Development of process for the production of arjuna herbal ghee from buffalo milk. Indian Journal Animal Sciences, 2017, 87 (2), pp. 203-207.

68. Banu C. Flavors, flavorings and flavor enhancers. In: Applications of additives and ingredients in the food industry, Ed. Asab, Bucharest, 2010, pp. 389-443. (rom)

69. Moro A. et al. Dairy matrix effect on the transference of rosemary essential oil compounds during cheese making. Journal of the Science of Food and Agriculture, 2015, 95, pp. 1507-1513.

70. Oliveira T. L. C. et al. Natural antimicrobials as additional hurdles to preservation of foods by high pressure processing. Trends in Food Science \& Technology, 2015, 45 (1), pp. 60-85. 